Brit. J. vener. Dis. (1959), 35, 35.

\title{
TREATMENT OF VAGINAL TRICHOMONIASIS WITH
}

\section{GYNO-STEROSAN*†}

\author{
BY \\ R. R. WILLCOX \\ St. Mary's Hospital, London, W.2
}

Vaginal infection with trichomoniasis is widespread and world-wide. Reported figures of incidence have varied from $5 \cdot 3$ per cent. in a birth control clinic (Whittington, 1951) to 20-30 per cent. in obstetrical and gynaecological clinics (Priddle and Gar Li, 1953; Kean and Day, 1954), amongst hospital patients in the U.S.A. (Davis, 1955), and cotton workers in China (Yang and $\mathrm{Li}, 1957$ ). Even higher rates have been recorded: 46-54 per cent. in pregnant Africans (Lambillon, Kangi, and Petepete, 1954); 53 per cent. in gynaecological patients before hysterectomy (Woodall, Waldrop, and Winkler, 1956); and 60 per cent. in prostitutes (Whittington, 1958).

The treatment agents used locally are so many as to indicate the unsatisfactory nature of all. In the chemical field these include the oldest, most tried, acetarsol (Cuthbert, 1955), arsenical and bismuth preparations (Reich, Nechtow, Rubenstein, and Doswald, 1955), copper sulphate (Lee and Keifer, 1954) amidonitrothiazole (Bushby, Catterall and Williamson, 1955), diiodohydroxy quinoline (Gready 1956), fluoroquine (Beiren, 1953), furazolidine (Rogers, Belloff, Paul, Yurchenco, and Gever, 1956), hexidine derivatives (Hoefer, Bailey, and Farley, 1957), mercurochrome (Ferguson and Edgerton, 1950), sodium lauryl sulphate (Carrow, 1955), sulphonamides (Karnaky, 1951), and tetronyl (Hundley, Diehl, and Baggott, 1950).

Hormones, e.g. stilboestrol (Tinsley, 1954) and cortisone (Roland, Yeprocsky, and Lenhart, 1956), have also been tried, as have many antibiotics, including anisomycin (Gardocki, Timmens, Wilson, Sodergren, Hettinger, and P'An, 1955), chlortetracycline (McVay, Laird, Flanagan, and Sprunt,

\footnotetext{
* Received for publication December 5, 1958.

+ Gyno-Sterosan tablets for vaginal insertion are manufactured by J. R. Geigy S.A., Basle. Each vaginal tablet contains $200 \mathrm{mg}$. $5: 7$ dichloro-8-hydroxyquinaldine.
}

1949), endomycin (Wilkins and Henshaw, 1954), oxytetracycline (Green, 1952), penicillin (Walker, Goldberger, and Lapid, 1951), polymyxin (Kistner and Duncan, 1954), trichomycin (Magara, Yokouti, Senda, and Amino, 1954), and tyrothricin (Iger and Kupperman, 1955). With the exception of penicillin, which has proved of little value, and cortisone, which is suppressive of symptoms only, most of these agents have been reported upon more or less favourably, but, while many have apparently equalled, none have improved upon, the oldest tried preparation acetarsol (Catterall and Williamson, 1955).

Failures are frequent, particularly after subsequent menstrual periods. The causes of failure have been considered to lie in external re-infection and internal re-infection from residual trichomonads in the urine and Skene's tubules (Nicol, Gallagher, and King, 1952). Indeed the surgical obliteration of Skene's ducts by electro-cautery has been recommended for chronic cases (Riba, 1956).

The need for an effective systemic drug has for long been apparent. The various substances so far tested by mouth have not met with success. These include aminitrozole (Willcox, 1957), atebrin (Hammer, De Groat, and MacGregor, 1954), chloroquine (Swartxwelder, Mulé, Frye, and Vella, 1955), trichomycin (Catterall and Nicol, 1957), and thyroid extract (Krieg, 1954). Although initial reports have sometimes indicated some possible limited activity, such attempts have so far met with failure. Even psychotherapy has been recommended (Filler, 1955).

It is thus evident that no really satisfactory treatment is available for vaginal trichomoniasis. Although the many new preparations may have improved aesthetic qualities and are better tolerated than acetarsol, and are effective also in vaginal thrush, which tends to alternate with vaginal trichomoniasis in some patients, there has been 
little improvement in the overall therapeutic results obtained.

With the above observations in mind, a trial has been made of Gyno-Sterosan tablets (Geigy) in the treatment of this troublesome condition. GynoSterosan is $5: 7$ dichloro-8-hydroxyquinaldine, which is active in both vaginal trichomoniasis (Kaufmann and Gehry, 1957; Rossel and Lavanchy, 1957; Schuldes, 1958) and vaginal thrush (Rossel and Lavanchy, 1957, Kaufmann and Gehry, 1957; Willcox, 1958). These tablets have been used in 49 patients with trichomonal vaginitis.

\section{Material}

There were 41 white patients and eight Negresses (seven from the West Indies and one from West Africa). Their average age was 27.4 years (range 17 to 54); 33 were single, fifteen were married, and one was a widow. They were predominantly young persons attending a venereal diseases clinic. Many were promiscuous and had had many previous venereal and quasi-venereal conditions. It was difficult to ensure that they completed treatment and that they attended properly for follow-up examination.

Fifteen patients had had no previous venereal disease but the remainder had had 22 attacks of gonorrhoea, 38 of vaginitis, seven of vaginal thrush, five of syphilis, four of non-specific cervicitis, two of salpingitis, and one each of condylomata acuminata and herpes genitalis. Two persons had attended as uninfected contacts of patients with gonorrhoea, making a total of 82 previous incidents or an average of 1.7 for the group.

Trichomonads were found by dark-field examination of wet specimens of vaginal discharge in all cases before treatment. Smears and cultures for gonococci were also made from the urethra and cervix in all cases. Gonococci were recovered from eight patients and these were also treated with penicillin. One patient had genital condylomata which were treated locally with podophyllin.

The Wassermann and VDRL (or Kahn) reactions were both negative in 47 cases, in one case the Wassermann reaction was negative and the VDRL test was weakly positive, and in one both tests gave positive results. The gonococcal complementfixation test was performed on sera from 44 cases, giving a negative result in 42 and a weakly positive result in two.

\section{Treatment Regimen}

All patients were instructed to insert two GynoSterosan tablets intra-vaginally each night before retiring. The intention was to treat all patients for 3 weeks. The default rate was high, however, and the results are assessed according to the number of weeks of treatment after which it was subsequently possible to observe the patients.

The pessaries were well tolerated. No complaints of burning, irritation, dysuria, or other side-effects were made. Only one patient complained that the tablets were messy and the stains difficult to remove from underclothing, and she not very vehemently.

\section{Follow-up and Results}

The follow-up and results obtained, irrespective of the duration of treatment, are shown in Table I.

TABLE I.

FOLLOW-UP AND RESULTS OF TREATMENT OF 49 CASES OF TRICHOMONAL VAGINITIS WITH GYNO-STEROSAN

\begin{tabular}{|c|c|c|c|c|}
\hline \multirow{3}{*}{ Follow-up } & \multirow{3}{*}{ Total } & \multicolumn{3}{|c|}{ Result } \\
\hline & & \multirow{2}{*}{$\begin{array}{l}\text { Satis- } \\
\text { factory }\end{array}$} & \multicolumn{2}{|c|}{ Vaginitis } \\
\hline & & & TV - & $\mathrm{TV}+$ \\
\hline $\begin{array}{c}0 \\
1-7 \text { days } \\
8-14 \text { days } \\
15-21 \text { days } \\
22-28 \text { days } \\
1-2 \text { months } \\
2-3 \text { months } \\
\text { Over } 3 \text { months }\end{array}$ & $\begin{array}{r}49 \\
43 \\
34 \\
31 \\
26 \\
21 \\
10 \\
1\end{array}$ & $\begin{array}{l}-8 \\
1 \\
2 \\
2 \\
7 \\
2 \\
1 *\end{array}$ & $\begin{array}{l}- \\
\frac{1}{1} \\
\frac{1}{1}\end{array}$ & $\begin{array}{l}-1 \\
2 \\
2 \\
3 \\
3 \\
3 \\
3\end{array}$ \\
\hline Total ... & 43 & 23 & 3 & 17 \\
\hline
\end{tabular}

* One had vaginal thrush.

Thus of 49 patients treated, 43 were followed. The results as regards vaginitis were satisfactory in 23 (53.5 per cent. of those followed), although one of these patients was found to have vaginal thrush after 3 months of observation. In no case was vaginal thrush observed to replace the trichomonal vaginitis within 3 months from the start of treatment.

The trichomonal vaginitis recurred in seventeen instances (39.5 per cent. of those followed); in three within 14 days, in eight within 1 month, in eleven within 2 months, and in fourteen within 3 months. Although treatment-failure is the likely explanation of the early recurrences, re-infection cannot be excluded in the later cases. In three instances ( $7 \cdot 0$ per cent.) a vaginitis recurred but no trichomonads were observed.

The results are related to the duration of therapy in Table II (opposite).

The best results were noted in patients receiving 2 to 3 weeks of treatment. Of 24 so treated all were followed and there were eight ( $33 \cdot 3$ per cent.) recurrences, in which trichomonads were again observed after treatment. 
TABLE II

RESULTS RELATED TO DURATION OF THERAPY

\begin{tabular}{|c|c|c|c|c|c|c|c|}
\hline \multirow{3}{*}{\multicolumn{2}{|c|}{ Duration }} & \multirow{3}{*}{$\begin{array}{c}\text { No. } \\
\text { Treated }\end{array}$} & \multirow{3}{*}{$\begin{array}{l}\text { No. } \\
\text { Fol- } \\
\text { lowed }\end{array}$} & \multicolumn{4}{|c|}{ Result } \\
\hline & & & & \multirow{2}{*}{$\begin{array}{l}\text { Satis- } \\
\text { factory }\end{array}$} & \multicolumn{2}{|c|}{ Vaginitis } & \multirow{2}{*}{$\begin{array}{c}\text { Per cent. } \\
\text { of those } \\
\text { followed } \\
\text { TV+ }\end{array}$} \\
\hline & & & & & TV- & TV+ & \\
\hline \multicolumn{2}{|c|}{$\begin{array}{r}7 \text { days } \\
14 \text { days } \\
21 \text { days }\end{array}$} & $\begin{array}{r}25 \\
7 \\
17\end{array}$ & $\begin{array}{r}19 \\
7 \\
17\end{array}$ & $\begin{array}{c}8 \\
5 \\
10^{*}\end{array}$ & $\frac{2}{1}$ & $\begin{array}{l}9 \\
2 \\
6\end{array}$ & $\begin{array}{l}47 \cdot 4 \\
28 \cdot 6 \\
35 \cdot 3\end{array}$ \\
\hline \multirow{2}{*}{ Totals } & No. & 49 & 43 & 23 & 3 & 17 & $39 \cdot 5$ \\
\hline & $\%$ & - & 100 & $53 \cdot 5$ & $57 \cdot 0$ & $39 \cdot 5$ & \\
\hline
\end{tabular}

* One patient had vaginal thrush after 3 months.

Although these results are perhaps not striking they are comparable to those obtained with acetarsol in a control series of patients treated with acetarsol pessaries. Of 23 treated 22 were followed. The results were adjudged satisfactory in fourteen, but trichomonads were again found in six and a vaginitis without trichomonads in two.

\section{Summary and Conclusions}

(1) The largely unsatisfactory nature of all treatments available for vaginal trichomoniasis is noted.

(2) 49 patients with vaginal trichomoniasis were treated with Gyno-Sterosan, two tablets being inserted nightly for 1 to 3 weeks.

(3) 43 patients were followed and there were seventeen recurrences in which $T$. vaginalis was found. Eight of these occurred within 4 weeks and nine after this time, some of which were probably re-infections. There were also three instances of clinical vaginitis after treatment, but trichomonads were not recovered from these cases.

(4) Only one instance of post-treatment vaginal thrush was noted and this was observed after 3 months. That Gyno-Sterosan is effective in vaginal thrush is indicated in a second communication (Willcox, 1959).

(5) The pessaries were well tolerated and no patient complained of any side-effects.

(6) The results obtained with Gyno-Sterosan in vaginal trichomoniasis are considered comparable to those obtained with acetarsol and other well-tried preparations. Gyno-Sterosan tablets have the added advantage of being effective against vaginal thrush.

Thanks are expressed to J. R. Geigy S.A., Basel, for providing the Gyno-Sterosan tablets used in this trial.

\section{REFERENCES}

Bieren, R. (1953). Med. Ann. D.C., 22, 17.

Bushby, S. R. M., Catterall, R. D., and Williamson, M. (1955). Brit. med. J., $1,78$.

Carrow, L. A. (1955). Quart. Bull. Northw. Univ. med. Sch., 29, 326.

Catterall, R. D., and Nicol, C. S. (1957). Brit. med. J., 1, 29.

C and Williamson, M. (1955), Brit. J. vener. Dis., 31, 119.

Cuthbert, K. J. R. (1955). Practitioner, 174, 222.

Davis, C. H. (1955). J. Amer. med. Ass., 157, 126.

Ferguson, R. T., and Edgerton, G. S. (1950). Virginia med. Monthly, 77, 643

Filler, W. (1955). Int. Rec. Med., 168, 557.

Gardocki, J. F., Timmens, E. K., Wilson, L. B., Sodengren, J. G., Hettinger, B. R., and P'An, S. Y. (1955). Antibiot. and Chemother, 5,490 .

Greene, H. J. (1952). Ibid., 2, 119.

Gready, T. G. (1956). Mississippi Doct., 33, 213.

Hammer, J. M., De Groat, A., and MacGregor, J. R. (1954). J. Mich. med. Soc., 53, 888 .

Hoefer, W. H. V., Bailey, F. A., and Farley, W. W. (1957). Antibiot. Med., 4, 31 .

Hundley, J. M., Diehl, W. K., and Baggott, J. W. (1950). Amer. J. Obstet, Gynec., 60, 977.

Iger, J., and Kupperman, H. S. (1955). Int. Rec. Med., 168, 723.

Kaufmann, P., and Gehry, L. (1957). Praxis, 46, 1156.

Karnaky, K. J. (1951). Postgrad. Med., 9, 220.

Kean, B. H., and Day, E. (1954). Amer. J. Obstet. Gynec., 68, 1510.

Kistner, R. W., and Duncan, C. J. (1954). Obstet and Gynec., 4, 155.

Krieg, E. G. M. (1954). J. Mich. med. Soc., 53, 749.

Lambillon, J., Kangi, T., and Petepete, A. (1954). Ann. Soc. belge Méd. trop., 34, 183

Lee, A. F., and Keifer, W. S. (1954). Northw. Med., (Seattle), 53, 1227.

McVay, L. V., Laird, R. L., Flanagan, J. B., and Sprunt, D. H. (1949). Proc. Soc. exp. Biol. (N.Y.), 72, 674.

Magara, M., Yokouti, E., Senda, T., and Amino, R. (1954). Antibiot. and Chemother, 4, 433.

Nicol, C. S., Gallagher, E., and King, A. J. (1952). Brit. J. vener. Dis., 28,142 .

Priddle, H. D., and Gar Li, G. (1953). Amer. J. Obstet. Gynec., 65, 166.

Reich, W. J., Nechtow, M. J., Rubenstein, M. W., and Doswald, A. M.'(1955). Illinois med. J., 108, 278.

Riba, L. W. (1956). A.M.A. Arch. Surg., 73, 833.

Rogers, G. S., Belloff, C. B., Paul, M.' F., Yurchenco, J. A., and Gever, G. (1956). Antibiot. and Chemother., 6, 231.

Roland, M., Yeprocsky, E. C., and Lenhart, W. (1956). Obstet, and Gynec., 7, 459.

Rossel, G., and Lavanchy, M. E. (1957). Praxis, 46, 968.

Schuldes, von H. (1958). Med. Klin., 53, 59.

Swartzwelder, J. C., Mule, J. G., Frye, W. W., and Vella, F. (1955). Med. Tms $(\ddot{N} . Y), 83,$.

Tinsley, W. H. (1955). Tex. St. J. Med., 51, 5.

Walter, R. I., Goldberger, M. A., and Lapid, M. S. (1951). N.Y. St. J. Med., $51,937$.

Whittington, M. J. (1951). J. Obstet Gynaec. Brit. Emp., 58, 398.

(1958). Bull. Inst. Techn. Venereol., 4, 61.

Wilkins, J. Rull. Inst. Techn. Venereol., 4, 61.

Willcox, R. R. (1957). Brit. J. vener. Dis., 33, 115.

(1959). "The Treatment of Vaginal Thrush with Gyno-Sterosan." In press.

Woodall, P. S., Waldrop, E. G., and Winkler, C. H. (1956). Obstet. and Gynec., 6, 283.

Yang, Y. C., and Li, T. F. (1957). Chin. J. Obstet. Gynec., 5, 19. 